інноваційного середовища на формування інноваційного потенціалу навчального закладу й способів самореалізації педагогів.

\title{
Література
}

1. Ващенко Л. М. Система управління інноваційними процесами в загальній середній освіті регіону : автореф. дис. ... д-ра пед. наук: 13.00.01 / Л. М. Ващенко. - К., 2006. - 45 с. 2. Дичківська І. М. Інноваційні педагогічні технології: [навч. посіб.]/ I. М. Дичківська. - К. : Академвидав, 2004. - 352 с. 3. Калініна Л. М. Інформаційне управління загальноосвітнім навчальним закладом: системи, процеси, технології: [монографія]/ Л. М. Калініна. - $\quad$ К. : $\quad$ Інформатор, 2008. - 472 с. 4. Кассина Р. С. Инновационная среда образовательного учреждения как интегральное средство профессионального развития учителя: автореф. дис. ... канд. пед.. наук : 13.00.08 / Р. С. Кассина. - Нижний Новгород, 2006. - 24 с. 5. Каташов А. І. Педагогічні основи розвитку інноваційного освітнього середовища сучасного ліцею: автореф. дис....канд. пед. наук: 13.00.01/ А. І. Каташов. - Луганськ, 2001. - 22 с. 6. Крутенко О. В. Виховання гуманістичних цінностей школяра у педагогічній спадщині О. А. Захаренка: автореф. дис.... канд. пед. наук: 13.00.01 / О. В. Крутенко. - ПереяславХмельницький, 2012. - 24 с. 7. Мануйлов Ю. С. Концептуальные основы средового подхода в воспитании / Ю. С. Мануйлов // Вестник Костромского государственного университета им. Н. А. Некрасова. - Т. 14. Серия: «Педагогика. Психология. Социальная работа. Ювенология. Социокинетика». - 2008. - № 4. - С. 21-27. 8. Саранов А. М. Инновационный процесс как фактор саморазвития современной школы: методология, теория, практика: [монография] / А. М. Саранов. - Волгоград : Перемена, 2000. - 259 с. 9. Тринитатская О. Г. Управление развивающей средой инновационного образовательного учреждения : дис. ... докт. пед. наук : 13.00.01 / О. Г. Тринитатская. Москва, 2009. - 512 с. 10. Ясвин В. А. Образовательная среда: от моделирования к проектированию: [монография] / В. А. Ясвин. - М. : Смысл, 2001. - 365 с.

\section{НАВЫК ПОСТРОЕНИЯ КОРРЕКТНОЙ СИТУАЦИОННОЙ ОСОЗНАННОСТИ В СТРУКТУРЕ ПРОФЕССИОНАЛЬНОЙ НАЛЁЖНОСТИ ЛЁТНОГО СОСТАВА}

Кушнір О. О. Навичка будування коректної ситуаційної усвідомленості у структурі професійної надійності льотного складу.

У статті наводиться обгрунтування необхідності розроблення та впровадження нових педагогічних підходів до підготовки майбутніх пілотів, а саме навчання побудові коректної ситуаційної усвідомленості. Аналізується поняття «ситуаційна усвідомленість», іiї сутність, алгоритм формування й значення для професійної надійності льотного складу.

Ключові слова: майбутні пілоти, професійна надійність, нетехнічні навички, індивідуальний стиль діяльності, управління психічною діяльністю, ситуаційна усвідомленість, образ польоту.

Кушнир О. А. Навык построения корректной ситуационной осознанности в структуре профессиональной надёжности лётного состава.

В статье приводится обоснование необходимости разработки и внедрения новых педагогических подходов к подготовке будущих пилотов, а именно обучения построению корректной ситуационной осознанности. Анализируется понятие 
«ситуационная осознанность», её сущность, алгоритм формирования и значение для профессиональной надёжности лётного состава.

Ключевые слова: будущие пилоты, профессиональная надёжность, нетехнические навыки, индивидуальный стиль деятельности, управление психической деятельностью, ситуационная осознанность, образ полёта.

Kushnir O. A. Skill formation of the correct situation awareness in the structure of professional reliability of flight crews.

The paper outlines the rationale for the development and implementation of new pedagogical approaches to the training of future pilots - namely, learning the correct form of situation awareness. The concept of «situation awareness», its essence, the algorithm of formation and implications for professional reliability of crews is analyses.

Key words: future pilots, professional reliability, non-technical skills, individual style of activity, mental activity management, situation awareness, the image of the flight.

С момента первого полёта человека на аппарате, тяжелее воздуха, и до сегодняшнего дня, самым сложным звеном в обеспечении безопасности полётов является психофизиология человека, пилотирующего воздушное судно. Ограничения и возможности человека - оператора особо сложных систем управления - находятся в центре пристального внимания и изучения учёных, ориентированных на повышение безопасности полётов. Однако статистика авиационных происшествий неуклонно указывает на то, что основной причиной подавляющего большинства авиапроисшествий авиации мира (80-90\%) является «человеческий фактор» $[5$, с. 10]. Поэтому исследования, направленные на повышение профессиональной надёжности лётного состава, являются наиболее актуальными для практики эксплуатации воздушного транспорта. Поиск соответствующих мер предотвращения авиационной аварийности требует структурного анализа понятия «профессиональная надёжность», поиска её компонентов, имеющих резервы для совершенствования и разработки соответствующих методик.

Цель статьи - на базе достижений авиационной психологии и анализа авиационной аварийности обосновать необходимость внедрения в педагогический процесс подготовки будущих пилотов методики обучения навыку формирования корректной ситуационной осознанности.

Подготовка специалиста в высшем учебном заведении направлена, в первую очередь, на формирование его профессионализма до степени, обозначенной как «профессиональная надёжность».

Н. Плотников определяет лётный профессионализм, как основное знание лётного оператора о том, как следует выполнять задачу (декларативное знание), и его способность выполнить задачу (процедурное знание), а также способность (навыки) оператора выполнить безопасный полет и эффективную перевозку [5]. Очевидно, что современная система профессиональной подготовки лётного состава обеспечивает оба блока необходимых пилоту знаний, а вопрос формирования и контроля наличия в нужной степени всех, необходимых способностей (навыков), остаётся открытым.

По классическому определению Р. Макарова, профессиональная надёжность пилота- это мера стабильности интеграции мотивационных, эмоциональных, интеллектуальных и психофизиологических компонентов деятельности, направленных на эффективное обеспечение профессиональных функций в экстремальных режимах, в заданное время [4, с. 130]. 
Следовательно, для решения актуальной задачи поиска путей совершенствования формирования профессиональной надёжности будущих пилотов необходим анализ компонентов интегрированного результата для определения значения каждого и возможностей повышения их резервов на современном этапе.

В работах В. Небылицына, Б. Ломова, К. Гуревича, О. Конопкина и других психологов, проблема эффективности и надежности труда человека рассматривается в свете учения о типах высшей нервной деятельности. Гипотеза о наличии связи между некоторыми характеристиками рабочих качеств человека-оператора и основными свойствами его нервной системы была выдвинута В. Небылицыным в 1964 г. [6]. Многолетние научно-практические исследования доказали, что определённые врождённые сочетания основных особенностей нервной системы предопределяют успешность человека в некоторых видах деятельности. Эта особенность обеспечения профессиональной надёжности была реализована введением в учебных заведениях лётного и диспетчерского профиля профессионально-психологического отбора. Однако вскоре стало ясно, что такой отбор обеспечивает профессиональную пригодность, но не профессиональную надёжность операторов особо сложных систем управления.

Дальнейшими исследованиями было установлено, что надежность деятельности хоть существенно и зависит от индивидуально-психологических особенностей личности, но требует особого целенаправленного формирования с использованием личностного и деятельностного подходов обучения [7]. Кроме того, ученые определили что у лиц, успешно прошедших профессионально-психологический отбор, в соответствии с закономерностями психического развития и формирования комплекса профессионально-важных качеств с индивидуальным стилем деятельности, фундамент профессиональной надёжности лётного состава формируется именно на этапе первоначальной лётной подготовки [3]. Т.е. период обучения будущих пилотов в вузе кардинально определяет успешность дальнейшего профессионального становления личности и обеспечивает фундамент профессиональной надёжности.

Долгое время ключевыми элементами профессиональной надёжности лётного состава считались факторы, связанные с физическим здоровьем пилота (выносливость, физическая сила, работоспособность и т. д.). Соответственно, поиск путей совершенствования профессиональной надёжности чаще всего находился в аспектах физической подготовки. Это работы К. Брыкова, А. Горелова, Т. Джамгарова, Р. Макарова, В. Марищука, А. Шакулы и других учёных [3]. Такой подход абсолютно соответствовал особенностям процесса пилотирования воздушных судов того времени. Управление самолётами, произведёнными до конца XIX века, требовало значительных физических возможностей лётного состава. Однако на современном этапе использование новейших технологий в авиационной технике кардинально преобразовало структуру профессиональной деятельности пилотов гражданской авиации. Приоритетные ранее физические профессионально важные качества востребованы сегодня, скорее, как резервные - для действий в определённых экстремальных ситуациях. Притом, что стандартный полёт на современном воздушном судне выдвигает значительно более высокие, чем ранее, требования к психофизиологическим особенностям членов экипажа. В первую очередь - к способностям по переработке больших объёмов сложной информации в условиях дефицита времени. Данное перераспределение приоритетов профессионально важных качеств лётного состава уже нашло своё отображение в нормативных документах ведущих авиакомпаний при отборе претендентов на трудоустройство, но ещё не учитывается в процессе профессиональной подготовки будущих пилотов. 
Учебно-тренировочный процесс обучения в лётных учебных заведениях традиционно предполагает последовательную реализацию алгоритма «знания»«умения»-«навыки» в области самолётовождения. Но практически не располагает технологиями и методиками обучения «нетехническим» навыкам. А именно наиболее рациональным навыкам управления собственными психическими процессами, алгоритмам мышления, корректной и эффективной работе воображения. Притом, что один из выдающихся лётчиков-испытателей мира генерал-полковник авиации М. Громов ещё в 60-ые годы прошлого столетия подчёркивал: «Надёжность полёта заключается не только в навыках техники пилотирования, но и в более трудном для освоения предмете - в надёжной психической деятельности во время полёта... А все эти ошибки возникают в результате неумения лётчиков следить за своей психической деятельностью во время полётов из-за отсутствия самоконтроля и незнания рациональных способов этой деятельности в трудовом процессе» [1]. Трансформация лётной деятельности пилотов гражданской авиации на современном этапе многократно увеличила актуальность данного утверждения. Техническое переоснащение самолётов нового поколения в разы увеличило требуемую скорость принятия решения. Изменились методы представления полётной информации, увеличилось её количество, усложнилось качество. Соответствие человека перечисленным преобразованиям авиационной техники может быть обеспечено только наличием у него особых психологических («нетехнических») навыков.

Следовательно - на современном этапе процесс профессиональной подготовки будущих пилотов в высшем учебном заведении требует совершенствования путём внедрения новых, научно обоснованных методик и технологий обучения нетехническим навыкам, влияющим на надёжность профессиональной деятельности.

Обучение управлению собственной психической деятельностью должно начинаться с моделирования требуемого состояния такой деятельности. Из работ авиационных психологов по данной проблематике $[5 ; 9 ; 10]$ известно, что в каждый момент времени пилот должен располагать ситуационной осознанностью. Понятие «ситуационной осознанности» ввёл в практическую психологию и обосновал Мик Эндсли. В его трактовке это: «чувственное восприятие элементов обстановки в едином пространственно-временном континууме, осознанное восприятие их значения, а также проецирование их в ближайшее будущее» [9]. На постсоветском пространстве чаще находил применение термин «образ полёта (оперативный или же концептуальный)», который представляет собой в обобщённом понимании некий психический акт отражения окружающей действительности в сознании лётчика. Или, в общепринятой формулировке: «факт отражения летчиком ситуации полета, формирования у него целостного представления о пространственном положении самолета и соответствии режима полета заданному» [8]. Хотя приведённые термины достаточно часто используют как синонимы, отметим принципиальное отличие первого- наличие экстраполяции в ближайшее будущее. Эксперты отечественной авиационной психологии подчёркивают динамичность самого образа [2]: «Формирование образа активный процесс, в ходе которого осуществляется все более полное и глубокое «вычерпывание» информации из окружающей человека действительности. Содержание образа непрестанно обогащается, уточняется и корректируется». Следовательно, по нашему мнению, корректная ситуационная осознанность представляет собой этот динамичный образ полёта в его последовательном развитии: максимально полная картина происходящего в текущий момент и множество вариантов её состояния в предстоящие моменты полёта. Таким образом, желаемая модель ситуационной осознанности состоит из совокупности образов полёта, в котором первый есть результат 
работы апперцепции, остальные - мышления и воображения. Дальнейший анализ указывает на то, что процесс формирования ситуационной осознанности состоит из ряда психических действий:

- восприятие информации от разных источников;

- интеграция полученной информации в единое целое (при получении противоречивой информации - определение приоритетности источников);

- экстраполяция интегрированного результата (образа полёта) на промежутки времени, заданные участком полёта и полётным заданием;

- формирование единой для экипажа ситуационной осознанности посредством коммуникаций.

Именно рациональному и корректному способу выполнения перечисленных психологических действий необходимо обучить будущего пилота на этапе наземного моделирования реальной лётной деятельности (тренажёрной подготовки). Известно, что навыки (особенно - психологические) не только используются, но и формируются в деятельности [4], на что и ориентирована существующая система обучения лётной работе. Однако при этом доказано так же, что индивидуальный стиль деятельности, сформировавшийся без целенаправленной работы по его моделированию, не всегда есть самым целесообразным и рациональным [7]. Когда речь идёт о таком сложном и ответственном труде, как лётный, риск обретения нерационального навыка содержит в себе угрозу безопасности полёта как предпосылку снижения профессиональной надёжности, а значит - должен быть сведён к минимуму. Особого внимания при разработке методики построения навыка корректной ситуационной осознанности заслуживает этап формирования образа полёта в условиях противоречивой информации. Так называемые иллюзии - проблемы в определении механизмов восприятия человеком времени, пространства, когнитивных процессов и связанные с этим искажения восприятия. Будущего пилота необходимо до начала лётной деятельности обучить распознавать противоречивую информацию, правильно определять приоритеты и экстраполировать полученный результат. Неумение управлять своей психической деятельностью в таких условиях приводит к потере пространственной ориентировки. По расчетам специалистов, удельный вес потерь пространственной ориентировки среди причин авиационных происшествий достигает 20 процентов, а известным барьером в разрешении этих проблем является отсутствие целостной картины и классификационных схем предмета исследования [5].

Таким образом, совершенствование профессиональной подготовки будущих пилотов в направлении «нетехнических навыков», обеспечивается формированием их умений и навыков строить ситуационную осознанность в первую очередь - в условиях противоречивой информации. Для чего необходимо в рамках соответствующей методики разработать надлежащие теоретические задания, активизирующие знания о возможных иллюзиях в полёте и правильность последующей психической деятельности. Такая работа в предполётный период поможет обеспечить формирование резервных возможностей по восприятию и переработке дополнительной информации на фоне основной профессиональной деятельности. Именно такие резервные возможности должны обеспечить повышение надёжности лётного труда.

\section{Литература}

1. Громов М. М. Тому, кто хочет летать и работать лучше: заметки о летной профессии / М. М. Громов. - М. : Гласность, 2012. - 318 с. 2. Завалова Н. Д. Образ в системе психической регуляции деятельности / Завалова Н. Д., Ломов Б.Ф., Пономаренко В. А. - М. : Наука, 1986. - 66 с. 3. Кушнир О. А. Методика формирования у будущих пилотов профессионально важных качеств в процессе тренажёрной 
подготовки: дис. ... канд. пед. наук : спец. 13.00 .02 «Теория и методика обучения (технические дисциплины)»/ Кушнир Ольга Александровна. - Кировоград, 2009. 282 c. 4. Макаров Р. Н. Основы формирования профессиональной надёжности лётного состава гражданской авиации : [учеб. пособ.] / Р. Н. Макаров - М. : Воздушный транспорт, 1990. - 384 с. 5. Плотников Н. И. Ресурсы воздушного транспорта: [монография] / Николай Иванович Плотников. - Новосибирск : НГАЭиУ, 2003. - 328 с. 6. Практикум по дифференциальной психодиагностике профессиональной пригодности / [редколл. : В. А. Бодров (отв. редактор) и др.]. - М. : ПЕР СЭ, 2003.768 с. 7. Шадриков Б. Д. Психология деятельности и способности человека: [учеб. пособ.] / В. Д. Шадриков. - М. : Логос, 1996. - 320 с. 8. Энциклопедический словарь: психология труда, управления, инженерная психология и эргономика / [редкол.: Б. А. Душков (отв. редактор) и др.]. - М. : Академический проект, 2005. - 848 с. 9. Endsley M. Pilot situation awareness: The challenge for the training community. In Proceedings of the Interservice/ Industry Training Systems Conference (I/ITSC), 1989. P. 111-117. Ft. Worth, TX: American Defense Preparedness Association. 10. Gibson J., Orasanu J., Villeda E., Nygren T. (Loss of situation awareness: causes and consequences. In R.S. Jensen \& R.L.A. (Eds.), Proceedings of the Eigth International Symposium on Aviation Psychology, 1997. - Vol. 2. - P. 1417-1421. - Columbus: The Ohio State University.

\section{Світлана Майданенко}

\section{АНАЛІЗ СТРУКТУРИ ОРГАНІЗАЦЇ̈ МЕТОДИЧНОЇ РОБОТИ В ПЕДАГОГІЧНОМУ УЧИЛИЩІ}

Майданенко С. В. Аналіз структури організації методичної роботи в педагогічному училищі.

У статті розмежовано внутрішню та зовнішню організацію методичної роботи в педагогічному училищі. Конкретизовано рівні внутрішньої організації методичної роботи.

Ключові слова: внутрішня організація, зовнішня організація, загальна структура, рівні внутрішньої структури.

Майданенко С. В. Анализ структуры организации методической работы в педагогическом училище.

В статье выделены внутренняя и внешняя организация методической работы в педагогическом училище. Конкретизированы уровни внутренней организации методической работы.

Ключевые слова: внутренняя организация, внешняя организация, общая структура, уровни внутренней структуры.

Maidanenko S. V. Analysis of the structure of organization of methodological work in the pedagogic professional school. The article highlighted the internal and external organisation of methodical work in the pedagogic professional school. Author specifies the levels of the internal organization of methodical work.

Key words: internal organization, foreign organization, the overall structure, levels of internal structure.

У реформуванні національної освіти в Україні важливого значення набуває організація методичної роботи у навчальних закладах, головною метою якої є допомога 